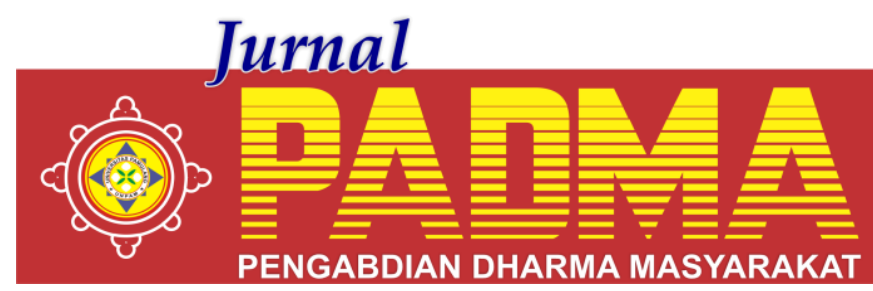

VOLUME 1, NOMOR 1, JANUARI 2021

\title{
PEMANFAATAN SAMPAH PLASTIK KERAJINAN RUMAH TANGGA TAMAN BELAJAR KREATIF MEKARSARI
}

\author{
${ }^{1 *}$ Widya Intan Sari, ${ }^{2}$ Mulyadi, ${ }^{3}$ Noryani, ${ }^{4}$ Nani Rusnaeni, ${ }^{5}$ Sudiarto \\ Universitas Pamulang, Tangerang Selatan, Banten, Indonesia \\ *dosen02451@unpam.ac.id
}

\begin{abstract}
Abstrak
Tujuan diselenggarakannya kegiatan Pengabdian Kepada Masyarakat ini adalah untuk Pemanfaatan Sampah Plastik Untuk Kerajinan Rumah Tangga Taman Belajar Kreatif Mekarsari yang sesuai dengan perkembangan jaman yang aktual dan terkini. Selain itu dapat menggerakkan para anggota Pengurus untuk dapat mengedukasi lingkungan dan menjadi program di era milenial seperti saat ini. Dengan menggunakan diskusi kelompok, penyuluhan ini mengedukasi pengelola Taman Belajar Kreatif Mekarsari akan pemanfaatan limbah plastic (bungkus kopi instan). Hasil kegiatan adalah meningkatkan motivasi berwirausaha oleh narasumber, kegiatan demonstrasi pembuatan produk usaha berbahan dasarsampah plastik serta kegiatan penyuluhan mengenai bagaimana hasil produk tersebut dibuat sebagai kegiatan wirausaha
\end{abstract}

Kata Kunci: Sampah Plastik, Kerajian Rumah Tangga

\section{Abstract}

The purpose of this Community Service activity is for the Utilization of Plastic Waste for Household Crafts Mekarsari Creative Learning Park in accordance with the development of the current and current era. In addition it can move the members of the Board to be able to educate the environment and become a program in the millennial era as it is today. By using group discussions, the education program educates the managers of Mekarsari Creative Learning Park on the use of plastic waste (instant coffee packs). The results of the activities are to increase entrepreneurship motivation by the resource persons, demonstration activities for the manufacture of products made from plastic waste and counseling activities on how the results of the products are made as entrepreneurial activities.

Keywords: Plastic Waste, Household Crafts

\section{PENDAHULUAN}

Program pengabdian kepada masyarakat merupakan salah satu program yang wajib dilaksanakan, baik oleh dosen maupun oleh mahasiswa, dengan berlandaskan pada prinsip-prinsip: motivasi pemenuhan kompetensi akademik, jiwa kewirausahaan (entrepreneurship), dan profesional serta kesehatan masyarakat khususnya anak-anak calon penerus bangsa, sehingga dapat menghasilkan program pengabdian kepada masyarakat yang bermutu, relevan, dan sinergis dalam meningkatkan pemberdayaan masyarakat.

Manajemen merupakan salah satu program studi di Universitas Pamulang. Program studi ini memiliki andil dalam mencetak lulusan yang berkarakter serta mampu bersaing di dalam dunia kerja, serta dapat berperan bagi pembangunan.
Pengabdian kepada masyarakat adalah bentuk Kegiatan pengabdian masyarakat merupakan salah satu Tri Dharma Perguruan Tinggi Selain Pendidikan dan Penelitian, sesuai undang-Undang RI Nomor 20 Tahun 2003 tentang Sistem Pendidikan Nasional, pada Pasal 20 ayat 2 dinyatakan: "Perguruan Tinggi berkewajiban menyelenggarakan pendidikan, penelitian dan pengabdian masyarakat". Pada Pasal 24 ayat 2 disebutkan:"Perguruan tinggi memiliki otonomi untuk mengelola sendiri lembaganya sebagai pusat penyelenggaraan pendidikan tinggi, penelitian ilmiah, dan pengabdian masyarakat".

Pengabdian kepada masyarakat merupakan pelaksanaan pengamalan ilmu pengetahuan, teknologi dan seni budaya langsung pada masyarakat secara kelembagaan melalui metodologi ilmiah 
sebagai penyebaran Tri Dharma Perguruan Tinggi serta tanggung jawab yang luhur dalam usaha mengembangkan kemampuan masyarakat, sehingga dapat mempercepat laju pertumbuhan tercapainya tujuan pembangunan nasional.

Program pengabdian kepada masyarakat merupakan salah satu program yang wajib dilaksanakan, baik oleh dosen maupun oleh mahasiswa, dengan berlandaskan pada prinsip-prinsip: motivasi pemenuhan kompetensi akademik, jiwa kewirausahaan (entrepreneurship), dan profesional, sehingga dapat menghasilkan program pengabdian kepada masyarakat yang bermutu, relevan, dan sinergis dalam meningkatkan pemberdayaan masyarakat.

Manajemen merupakan salah satu program studi di Universitas Pamulang. Program studi ini memiliki andil dalam mencetak lulusan yang berkarakter serta mampu bersaing di dalam dunia kerja, serta dapat berperan bagi pembangunan. Pengabdian kepada masyarakat adalah bentuk Kegiatan pengabdian masyarakat merupakan salah satu Tri Dharma Perguruan Tinggi Selain Pendidikan dan Penelitian, sesuai undang-Undang RI Nomor 20 Tahun 2003 tentang Sistem Pendidikan Nasional, pada Pasal 20 ayat 2 dinyatakan: "Perguruan Tinggi berkewajiban menyelenggarakan pendidikan, penelitian dan pengabdian masyarakat". Pada Pasal 24 ayat 2 disebutkan:"Perguruan tinggi memiliki otonomi untuk mengelola sendiri lembaganya sebagai pusat penyelenggaraan pendidikan tinggi, penelitian ilmiah, dan pengabdian masyarakat".

Pengabdian kepada masyarakat merupakan pelaksanaan pengamalan ilmu pengetahuan, teknologi dan seni budaya langsung pada masyarakat secara kelembagaan melalui metodologi ilmiah sebagai penyebaran Tri Dharma Perguruan Tinggi serta tanggung jawab yang luhur dalam usaha mengembangkan kemampuan masyarakat, sehingga dapat mempercepat laju pertumbuhan tercapainya tujuan pembangunan nasional.

Kantong plastik yang sudah dibeli ternyata pada akhirnya tetap dibuang dan menjadi sampah. Bermula dari inisiatif para pecinta lingkungan mencoba melihat ini sebagai permasalahan sekaligus peluang.
Mereka berinisiatif untuk mendaurulang sampah kantong plastik itu jadi sesuatu yang berguna. Taman Belajar Kreatif Mekarsari yang berisi anak-anak muda dapat mengembangkannya menjadi salah satu kegiatan belajar kreatif sekaligus berupaya untuk tidak menjadi salah satu penyumbang sampah yang sangat mengganggu lingkungan serta menciptakan solusi untuk permasalahan sampah di lingkungan. Pelatihan daur ulang tersebut berawal dari keresahan yang melihat banyak sampah plastik bekas bungkus kopi dan minuman instan lainnya yang hanya dibuang begitu saja.

Dari kondisi tersebut, mereka melihat adanya peluang untuk memanfaatkannya menjadi sesuatu yang bermanfaat. Pelaksanaan kegiatan dimulai dengan penyampaian materi secara langsung di depan peserta pelatihan. Kemudian dilanjutkan dengan praktik daur ulang sampah plastik menjadi berbagai macam kerajinan tangan dengan pendampingan tim ahli. kegiatan tersebut bertujuan untuk membantu mengurangi keberadaan sampah plastik di lingkungan. Selain itu juga dapat digunakan untuk meningkatkan ekonomi dan kreativitas masyarakat setempat. Diharapkan dengan adanya program ini, Taman Belajar Kreatif Mekarsari dan juga masyarakat di sini bisa melihat dan mengambil peluang dengan memanfaatkan bungkus plastik bekas kopi menjadi tas dan dompet atau perlengkapan rumah tangga. Sehingga nantinya akan mampu untuk membantu meningkatkan perekonomian mereka.

Program pengabdian kepada masyarakat merupakan salah satu program yang wajib dilaksanakan, baik oleh dosen maupun oleh mahasiswa, dengan berlandaskan pada prinsip-prinsip: motivasi pemenuhan kompetensi akademik, jiwa kewirausahaan (entrepreneurship), dan profesional, sehingga dapat menghasilkan program pengabdian kepada masyarakat yang bermutu, relevan, dan sinergis dalam meningkatkan pemberdayaan masyarakat. Manfaat Pengabdian Keapda Masyarakat

Kegiatan pengabdian kepada masyarakat dari tim dosen dan mahasiswa Universitas Pamulang hadir di Pengurus Taman Bermain Kreatif Mekar Sari, serta 
berbagi pengetahuan dan wawasan dengan bentuk penyuluhan yang menggunakan teknik group discussion untuk lebih dapat Pemanfaatan Sampah Plastik Untuk Kerajinan Rumah Tangga. Penyuluhan yang bertujuan menumbuhkan jiwa kepemimpinan pada anggota Pengurus ini semata-mata untuk membangun kesadaran sosial dan kreatifitas menyelesaikan permasalahan, terutama menanamkan rasa percaya kepada anggota dan semangat memotivasi dengan pendekatan milenial yang tentunya akan menjadi modal yang kuat dalam menciptakan program-program di masyarakat yang bagus dan kekinian.

\section{METODE}

Dengan menggunakan diskusi kelompok, penyuluhan ini mengedukasi pengelola Taman Belajar Kreatif Mekarsari akan pemanfaatan limbah plastic (bungkus kopi instan) Akhir-akhir ini berita mengenai limbah plastik semakin mengkhawatirkan. Pasalnya limbah plastik ini bukan hanya ada di daratan saja, melainkan di lautan. Namun tak semua yang berbahan plastik harus berakhir menjadi limbah. Pasalnya ada pula yang menggunakan plastik sebagai bahan kerajinan dan juga meningkatkan kreativitas. Salah satu yang sering digunakan ialah bungkus kopi. Bungkus kopi sendiri cukup sering dikreasikan menjadi berbagai hal seperti dompet maupun tas, terutama oleh para ibu-ibu pelaku UKM.

Cara membuat tas dari bungkus kopi ini termasuk ramah lingkungan. Karena bisa membantu untuk mengurangi sampah plastik. Selain itu, tentu saja hasil dari kerajinan ini bisa kamu gunakan dan juga ramah lingkungan. Untuk cara membuat tas dari bungkus kopi ini pun membutuhkan tingkat kreativitas serta keahlian. Tapi bila kamu belum bisa dan mengetahui cara membuat tas dari bungkus kopi, kamu bisa berlatih secara mandiri ataupun dengan bantuan orang lain. Karena sampah plastik sendiri termasuk dalam jenis sampah yang susah terurai, maka mendaur ulang dengan cara membuat tas dari bungkus plastik ini patut untuk kamu coba. Bahkan tas daur ulang ini bisa digunakan untuk menaruh barang saat berbelanja.

\section{HASIL DAN PEMBAHASAN}

Pengelolaan sampah melalui pendekatan sumber memungkinkan pengelolaan sampah secara terpadu mulai dari hulu sampai ke hilir (Purwaningrum, 2016a). Partisipasi masyarakat merupakan aspek terpenting dalam kegiatan pengelolaan sampah terpadu ini (Sulistiyorini, Darwis, \& Gutama, 2016).Partisipasi merupakan suatu keterlibatan masyarakat untuk berperan secara aktif dalam suatu program yang diusulkan. Partisipasi masyarakat tidak dapat dipaksakan, dan memerlukan waktu dan usaha yang berkelanjutan.

Partisipasi masyarakat akan meningkat apabila masyarakat mengetahui nilai lebih dan keuntungan-keuntungan yang diperolah bagi individu mau pun lingkungan mereka sendiri jika melakukan pengelolaan sampah secara mandiri.

Suatu program pengelolaan kebersihan lingkungan, khususnya sampah tidak akan berhasil dengan baik bila hanya mengandalkan peran pemerintah. Pengenalan dan penerapan prinsip 3R (Reduce, Reuse, Recycle) atau pengurangan, penggunaan kembali dan mendaur ulang sampah, merupakan salah satu cara pendekatan sumber dalam pengelolaan sampah (Kementerian Pekerjaan Umum, 2010). Dengan konsep ini masyarakat tidak hanya membuang sampah tapi sekaligus memanfaatkannya dan dapat mempunyai nilai tambah secara ekonomi.Sudah saatnya masyarakat mengubah paradigma sampah dari barang yang tidak berguna menjadi sesuatu yang bernilai ekonomi dan dapat dimanfaatkan.Pengelolaan sampah yang paling sederhana seperti memisahkan sampah organik dan anorganik di masyarakat merupakan kunci awal penerapan konsep 3R.

Pengenalan dan penerapan prinsip 3R (Reduce, Reuse, Recycle) atau pengurangan, penggunaan kembali dan mendaur ulang sampah, merupakan salah satu cara pendekatan sumber dalam pengelolaan sampah. Dengan konsep ini masyarakat tidak hanya membuang sampah tapi sekaligus memanfaatkannya dan dapat mempunyai nilai tambah secara ekonomi (Purwanto, Fatimah, \& Partono, 2013). 
Pengurangan sampah plastik menjadi hal yang penting karena sebagian besar wadah yang digunakan dalam aktivitas manusia terbuat dari plastik, sementara plastik sendiri merupakan bahan yang tidak mudah terurai di lingkungan, memerlukan waktu lama sampai puluhan tahun untuk dapat terdekomposisi. Masih sedikitnya partisipasi masyarakat terhadap pengelolaan sampah yang berwawasan lingkungan menunjukkan sangat diperlukannya usaha yang intensif dan berkesinambungan untuk meningkatkan partisipasi masyarakat terhadap pengelolaan sampah di lingkungannya secara mandiri.

Partisipasi publik merupakan kunci keberhasilan untuk mewujudkan kota yang bersih, hijau dan teduh sekaligus meraih Adipura dan menghilangkan citra kota terkotor se-Indonesia.

Banyak hal yang bisa dilakukan disana terutama kegiatan edukasi dan pengembangan softskill para pengurus ataupun pemuda Karang Taruna Mereka mengajak para anak-anak muda yang peduli dengan desa untuk ikut proyek pendidikan dan sosial ke masyarakatan. Dan membuka kegiatan yang bersifat pengabdian kepada masyarakat untuk dilaksanakan disana.

Proses daur ulang sampah plastik dimulai dengan membersihkan bungkus plastik dari sisa isi yang masih tersisa. Kemudian dipilih bagian yang ingin dijadikan sebagai motifnya. Gunting bagian tepi atas dan bawah. Kemudian lipat bagian atas dan bawah ke arah dalam dengan lebar sekitar 2 $\mathrm{cm}$. Setelah lipatan plastik terkumpul cukup banyak, anyam lipatan-lipatan tersebut sesuai bentuk yang diingankan (misalnya, tas). Kemudian anyaman yang sudah selesai dianyam, bagian dalamnya diberi kain sebagai pelapis. Satukan anyaman dan kain dengan cara dijahit, beri ritsleting dan tali sebagai pegangan tas.

Taman Belajar Kreatif Mekarsari memiliki kesempatan untuk berperan penting dalam mengembangkan generasi muda khususnya dalam bidang sosial, namun masih memerlukan masukan-masukan berupa pelatihan untuk memperkaya pemahaman mereka demi menciptakan program-program belajar yang lebih baik.

\section{PENUTUP}

Acara kegiatan pengabdian kepada masyarakat ini dilaksanakan selama 3 hari, yaitu sebagai berikut.Pertama, pembukaan oleh Ketua Pengurus Taman Belajar Kreatif Mekar Sari kemudian dilanjutkan laporan dari Ketua Kegiatan sekaligus penjelasan pelatihan dan pembagian bahan praktek dan contoh model produk.Selanjutnya yaitu pemberian motivasi berwirausaha oleh narasumber.Kedua, kegiatan demonstrasi pembuatan produk usaha berbahan dasar sampah plastik.Ketiga yaitu kegiatan penyuluhan mengenai bagaimana hasil produk tersebut dibuat sebagai kegiatan wirausaha.

\section{DAFTAR PUSTAKA}

Akbar, I. R. (2020). Pengaruh Kompensasi Dan Etos Kerja Terhadap Komitmen Organisasi Pada Pt. Central Buana Mandiri. Value: Jurnal Manajemen dan Akuntansi, 15(1), 73-80

Freddy Rangkuti. 2002. Measuring Customer Satisfaction(cetakan ketiga).Jakarta: PT.Gramedia Pustaka Utama.

Ghozali, Imam. 2000. Aplikasi Analisis Multivariate dengan SPSS. Semarang: Universitas Diponegoro.

Rozi, A., Agustin, F., Hindriari, R., Rostikawati, D., \& Akbar, I. R. (2020). The Effect Of Leadership On Employee Performance at PT. Stella Satindo In Jakarta. HUMANIS (Humanities, Management and Science Proceedings), 1(1).

Sarwani, S., Akbar, I. R., Handoko, A. L., \& Ilham, D. (2020). Pengaruh Pelatihan dan Motivasi terhadap Produktivitas Kerja Karyawan pada PT. Lion Mentari Airlines Bandara Internasional Soekarno Hatta Cengkareng. Jurnal Ilmu Komputer dan Bisnis, 11(2a), 91100.

Yuangga, K. D., \& Sunarsi, D. (2020). Pengembangan media dan strategi pembelajaran untuk mengatasi permasalahan pembelajaran jarak jauh di pandemi covid-19. JGK (Jurnal Guru Kita), 4(3), 51-58. 